\title{
Organic seed treatments of vegetables to prevent seedborne diseases
}

\author{
D. Spadaro ${ }^{1, a}$, J. Herforth-Rahmé 2 and J. van der Wolf ${ }^{3}$ \\ ${ }_{1}^{1}$ Dept. Agricultural, Forestry and Food Sciences (DISAFA), University of Torino, 10095 Grugliasco (TO), Italy; \\ ${ }^{2}$ Research Institute of Organic Agriculture (FiBL), 5070 Frick, Switzerland; ${ }^{3}$ Plant Research International, \\ Wageningen UR, 6700AA Wageningen, The Netherlands.
}

\begin{abstract}
Seedborne pathogens of vegetables are responsible for the re-emergence of diseases of the past, as well as the introduction of diseases into new geographical areas. Seed treatment can be used to eradicate seedborne pathogens or to protect from soilborne pathogens. The European Commission Regulation (EC) No. 1452/ 2003 states that only organic seeds must be used in organic horticulture. Starting crop production with clean seeds is the background for a healthy crop. Physical seed treatments, including mechanical treatments, thermal treatments, radiations, and redox treatments can be highly effective. The use of natural compounds, which could be of organic or inorganic nature, is another useful tool. Organic compounds comprise plant extracts, essential oils, as well as purified microorganism compounds. Biological control, based on the use of antagonistic microorganisms, can be effective and sustainable to control seedborne diseases. Indigenous or introduced seed-associated microorganisms might suppress seed infections by pathogens. Numerous filamentous fungi, yeast, and bacteria have been studied as biological control agents against seedborne pathogens. Microbial interactions on the spermosphere should be deeply investigated in order to develop effective BCAs. Seed treatments with elicitors may be helpful to initiate a defence response already early in plant development and has the advantage of being applied in a contained environment. The main advantages and drawbacks for every type of seed treatment will be described, together with the mains knowledge and technology gaps concerning vegetable crops. The cost-effectiveness of the seed treatments will be considered. Integrated control strategies, including different seed treatments, could be helpful to guarantee a high level of disease control and production yield.
\end{abstract}

Keywords: seedborne pathogens, seed dressing, seed health, copper, induced resistance, essential oils, thermotherapy, biological control

\section{INTRODUCTION}

Seedborne pathogens of vegetables, including viruses, viroids, bacteria, or fungi are responsible for the re-emergence of diseases of the past, as well as the introduction of diseases into new geographical areas. In a global economy, seed and propagation material account more than ever for the global movement of plant pathogens. The choice of a proper location, possibly isolating seed and seedling production locations from the environment, and the application of good agricultural practices, by managing the risk factors, are critical for producing a high-quality, pathogen-free seed crop. To minimize fungal and bacterial diseases, vegetable seeds are often produced in areas with low humidity and dry summer climate. An accurate and constant monitoring with reliable diagnostic tools during the growing season of both seed crop permits to early detect potential seedborne pathogens and are critical in a disease management strategy.

The European Commission Regulation (EC) No. 1452/2003 states that only organic seeds must be used in organic horticulture. Derogation of this rule is allowed if organic seeds are not available on the market, but conventional seeds should not be chemically treated.

${ }^{\mathrm{a} E}$-mail: davide.spadaro@unito.it 
There is the possibility to use conventional seed only if the variety a user wants to use is not registered in a database listing all commercially available organic seeds (http://ec.europa.eu/ agriculture/organic/eu-policy/eu-rules-on-production/seeds-database/index_en.htm).

Similar regulations are in effect in the United States and in other countries.

Seed treatments can be used to eradicate seedborne pathogens or to protect from soilborne pathogens. Seed treatments can disinfect the seed surface, thus eliminating seedborne pathogens. Some applications penetrate deeper in the seed to control seedborne pathogens for which a surface disinfection is not enough. These kinds of treatments are particularly delicate as they can internally damage the seed internally and affect the germination capacity. Different strategies have been developed during the last years for the control of seedborne pathogens of organic seeds, including physical seed treatments, treatments with natural compounds and biocontrol agents, and seed treatments with elicitors of induced resistance. The main seed treatments will be described in the current review, together with the main knowledge and technology gaps concerning vegetable crops.

\section{PHYSICAL TREATMENTS}

Physical treatments include mechanical treatments (sorting and brushing), thermal treatments (warm water, aerated steam or hot air), ultrasonic treatments and radiations (with microwaves resulting in elevated temperatures), UV-C light and redox treatments as with cold plasma and electrons.

\section{Thermotherapy}

For an effective treatment with hot water, the temperature of the seed batch should be raised quickly to a level detrimental for the pathogen but not for the seed, after the treatment temperatures should be lowered quickly. Typically, seeds are treated for 10-30 min between 50 and $55^{\circ} \mathrm{C}$. Pre-soaking of seeds in cold water to remove air and enhance heat transfer is described (Baker, 1962), but it is unclear if it is also practiced, as detailed protocols are the propriety of seed companies. Soaking of seed requires re-drying which should be done rapidly to avoid recolonization of the sterile surface of seeds with detrimental microorganisms. Heat transfer in hot air is less efficient than in water and treatments will last longer than hot water treatments. Also for hot air, relatively simple ovens can be used. As a result, seeds can become dehydrated and they may require rehydration. Dry heat has been successfully applied for bacteria and fungi, but also for viruses (Ling, 2010). For treatment of seeds with aerated steam, an equipment is required where seeds are successively placed in a thin layer and treated homogeneously for some time with vapour injected from a steam generator. After treatment, seeds are placed in a cooling chamber for quick cool down and drying (Forsberg, 2004).

In thermotherapy, the window between killing the pathogen and seed damage is often small and a precise control of the intensity and duration of the treatment is required. In particular, for large seeds, such as for legumes, an effective thermotherapy is difficult without seed damage (Grondeau et al., 1994). Seed lots, even those of the same cultivar, may largely differ in sensitivity for the treatment. The sensitivity may be dependent on the ripeness of the seed, the water content, or the seed storage period (Forsberg, 2004).

\section{Other physical treatments}

Sorting procedures are used as a standard in vegetable seed production to sort out aberrant seeds, which are too light, too small, discoloured, spotted or wrinkled. The aberrancy may be due to infections with seed-borne pathogens. Sorting procedures have also been developed based on chlorophyll fluorescence measurements of intact seeds, which could be related to the seed maturity (Groot et al., 2004). Also brushing of seeds will remove chaff, soil and plant debris that may potentially be contaminated with harmful pathogens. It may also directly remove the pathogen.

The potential of microwaves to elevate temperatures in seed has also been explored. Pectobacterium carotovororum was destroyed on tobacco seeds after a 20 min treatment at $625 \mathrm{~W}$, without affecting germination (Hankin and Sands, 1977). The efficacy of microwave 
treatments seems largely dependent on the pathosystem. In the same study cabbage and in particular bean seeds were very susceptible for the microwave treatment. Studies on fungal pathogens in wheat, showed that microwave treatments could not eliminate the pathogen significantly without causing seed damage (Knox et al., 2013).

Ultrasound has also been used to reduce inoculum load of mainly fungal pathogens on seed. Typically, frequencies in the range of $20-100 \mathrm{kHz}$ are used to generate a powerful cavitation that can destroy and detach microorganisms from surfaces (Sagong et al., 2011).

A seed treatment with low energy electrons was developed to control seed-borne pathogens on cereals (Burth et al., 1991). The electrons have a limited penetration depth of $0.025-0.5 \mathrm{~mm}$, and only penetrate the seed coat where they will kill pathogens leaving endosperm and embryo unaffected. Seed treatment with accelerated electrons reduced the level of seed infestation with Alternaria spp. and was particularly efficacious (50-100\%) against $A$. radicina (Jahn and Puls, 1998). The method was also effective for carrot seeds infected with Xanthomonas hortorum pv. carotae (Jahn and Puls, 1998).

Low pressure cold plasma treatments using air gases were used to inactive Aspergillus and Penicillium spp. on seed surfaces (Selcuk et al., 2008). Treatment of rice seed with the non-thermal plasma for $76 \mathrm{~s}$ resulted in a $90 \%$ level of control against Gibberella fujikuroi, the causative agent of bakanae disease (Jo et al., 2014).

Seed treatments with UV-C, UV light with a low wavelength between 100-280 nm, can be used to eliminate seed-borne pathogens. UV-C possesses germicidal properties through to the photochemical damage of the DNA of viruses and microorganisms (McDonald et al., 2000). Seed treatments of 60-120 min largely eliminate fungal pathogens without damage to the seeds. UV-C seed treatments applied in a low dose can also induce resistance in plants. Treatments of cabbage seeds with a low dose of $3.6 \mathrm{kJm}$ UV-C reduced the percentage of plants affected by black rot caused by Xanthomonas campestris pv. campestris with $40-90 \%$ dependent on the time seeds were stored after treatment (Brown et al., 2001).

\section{USE OF ORGANIC NATURAL COMPOUNDS}

The use of natural compounds, which could be of organic or inorganic nature, is another useful tool. Organic compounds comprise plant extracts, essential oils, as well as purified microorganism compounds. There are different forms of plant extracts. Extractions are performed on specific parts of the plant containing the active ingredient. The plant material is usually dried and grinded. In an aqueous extract, water is used as the solvent for the active ingredient. A liquid extract is prepared by maceration or percolation generally using ethanol at a suitable concentration or water, or else a soft or dry extract is dissolved into a liquid. Dry extracts are obtained after evaporation of the solvent used for their extraction. Essential oils/oil extract are the aromatic compounds of plants and are collected and concentrated by distillation. In some cases, they can be obtained through expression (i.e., cold press).

Most of the studies about seed disinfection with natural compounds have focused on cereal seedborne pathogens. Van Der Wolf et al. (2008) tested essential oils (e.g., thyme, oregano, cinnamon, clove), organic acids and plant extracts (Biosept, Tillecur, stinging nettle, golden rod) for the disinfection of vegetable seeds. Thirty minutes treatments with certain essential oils eliminated $99 \%$ of the bacteria on cabbage seeds, reduced fungi in blotter tests. High concentration of organic acids $(>2.5 \%)$ reduced bacteria on seeds. However, for certain products such as propionic acid, cinnamon oil and Biosept, a concentration higher than $1 \%$ had negative effect on seed germination. Of all the treatments, thyme oil was found to be the most promising. Shukla et al. (2002) screened essential oils in vitro against fungus causing wilt disease in pigeon pea, and found the oil of Trachyspermum ammi very efficient even at low concentrations.

Tinivella et al. (2009) tested different alternatives to chemical treatments against the pathogens causing anthracnose on bean and Ascophyta blights on pea. They applied dry and liquid plant extracts on naturally infested seeds. Tillecur and thyme oil were the only botanicals with some effect on the control of Ascochyta spp. and anthrachnose, respectively. Similarly, Schmitt et al. (2009) found that thyme oil (1\%) was effective against Phoma 
valerianellae on lamb's lettuce seeds.

One problem of using plant extracts is the high amounts of water needed as well as the necessity of a drying step afterwards. A sonication procedure was developed to obtain a stable emulsion of essential oils in water. The activity may be possibly enhanced by the addition of chelating divalent cations, which stabilize the anionic lipopolysaccharide layer in the outer membrane of Gram-negative bacteria (Skandamis et al., 2001).

Organic acids such as lactic or acetic acid are used but not registered as crop protection agents (Van Der Wolf et al., 2008). Seed treatment with acetic acid would be cost effective, since it is a cheap substance and unsold treated seeds could be used for feeding. Lizot et al. (2002) have found that soaking carrot seeds in vinegar was efficient against Altenaria dauci. Adding oligoelements to the vinegar increased this effect. It was not clear for them whether the vinegar was acting as a surface disinfectant during the soaking or whether it had a penetrating activity on the seeds during germination.

\section{USE OF INORGANIC NATURAL PRODUCTS}

Inorganic compound are naturally occurring minerals, like copper, phosphates, sulphur, clay and potassium bicarbonates. These natural compounds are generally reported for their use as plant or fruit treatments. There are only rare applications of inorganic compound for seed treatment. In a search for seed treatments against bacterial pathogens, Kasselaki et al. (2011) tested acidified nitrite against the growth of Alternaria on Brassica seeds and against bacterial canker (Clavibacter michiganensis subsp. michiganensis) in tomato and compared it to copper hydroxide. They found acidified nitrite to be partially efficient with high concentration affecting germination negatively. On the other hand copper hydroxide was $100 \%$ effective. The release of copper in the seed is minimal as it is less than the copper content of the harvested crop. However, currently available treatments for seedborne bacterial pathogens (e.g., copper fungicides) are only partially effective, and the control of bacterial seed diseases remains a challenge in both organic and conventional production (Brandl and Biddle, 2001). Copper based products remain the only chemical permitted in organic agriculture. Copper (copper oxychloride and copper hydroxide) is used as a mineral treatment against seed borne diseases. On cereals seeds $200 \mathrm{~g} \mathrm{Cu}$ are used on $100 \mathrm{~kg}$ seeds. The release of copper in the seed is minimal as it is less than the copper content of the harvested crop. Nevertheless, $\mathrm{Cu}$-based treatments of vegetable seeds remain scarce.

\section{ANTAGONISTIC MICROORGANISMS}

Biological control, based on the use of antagonistic microorganisms, can be an effective and sustainable strategy to control seedborne diseases. Indigenous or introduced seed-associated microorganisms might suppress seed infections by pathogens. Numerous filamentous fungi, yeast, and bacteria have been studied as biocontrol agents (BCAs) against seedborne pathogens. The literature specifically describing control of seedborne diseases by microbial antagonists is nevertheless limited compared to the huge number of reports on microbial control of other kinds of plant diseases.

Microbial interactions on the spermosphere should be deeply investigated in order to develop effective BCAs. To be effective against plant pathogens, a BCA must be able to successfully colonise the plant rhizosphere, to inhibit the attack of pathogens and to compete with other microorganisms in the plant rhizosphere.

The survival and establishment of BCAs in the spermosphere before sowing and in the rhizosphere after seed germination is essential for disease control. Bacterial isolates, such as Pseudomonas chlororaphis and P. fluorescens, declined in number over time in the rhizosphere, while a fungal isolate of Clonostachys rosea increased in number on both onion and carrot (Bennett and Whipps, 2008). Screening procedures should preferably start using seed-borne microbial populations, either the epiphytic or the endophytic one, whereas the majority of microorganisms currently used as BCAs originate from plants, especially from the rhizosphere (Köhl et al., 2011). Screening procedures should also consider the target crop, as different crops harbour distinct microbiota on their seed surfaces (Links et al., 
Microbial antagonists use different mechanisms to control plant pathogens, including nutritional competition, hyperparasitism, production of lytic enzymes, secretion of antibiotics, and interference with quorum sensing (Mukerji and Chincholkar, 2007). Microorganisms may also elicit localized and systemic host defences. Understanding the mechanism of action is crucial to develop optimal commercial formulations and application procedures in order to maximize the efficacy of BCAs (Spadaro and Gullino, 2005).

Several studies have shown the potential of using fungal, yeast and bacterial microorganisms for seed treatment against plant pathogens (Gilardi et al., 2005; Matarese et al., 2012). Trichoderma spp. as seed treatments was shown to effectively control soil- and seedborne pathogens such as Pythium, Phytophthora, Rhizoctonia and Fusarium spp. in different crops (Bennett et al., 2009; Wharton et al., 2012). Other BCAs used for seed coating are the plant-growth promoting rhizobacteria (PGPR), a group of bacteria that colonise the rhizosphere and produce hormones, vitamins and growth factors that improve plant growth and increase plant yield. PGPR such as Pseudomonas and Bacillus species have attracted much attention for their role in reducing plant diseases. When applied as seed treatments, PGPR resulted in significant reduction of Phytophthora blight disease of squash (Zhang et al., 2010).

Formulation is the crucial issue for commercial inoculants to ensure efficacy, storability and compatibility with existing agricultural technologies and practices. This industrial process can determine the commercial success or failure of a BCA with outstanding performance in controlled conditions. One way of delivery of microorganisms to vegetable seed is by adding them during priming or pelleting (Bennett et al., 2009; Jensen et al., 2004; Pill et al., 2009).

Only few microbial formulations are commercially available for the control of seedborne pathogens, including strains of Bacillus subtilis (Kodiak, Bayer CropSciences), Streptomyces grieseoviridis (Mycostop, Verdera), Gliocladium virens (SoilGard, Certis), Trichoderma harzianum (T-22 Planter Box, BioWorks), and Streptomyces lydicus (Actinovate, Natural Industries). In practice, the protection effect of biocontrol agents is often inconsistent and limited in comparison to a chemical treatment. Furthermore, there are commercial constraints like development costs in relation to market size, the feasibility of mass-production, difficulties with formulation, and general difficulties associated with the registration of microbials as plant protection products.

\section{INDUCED RESISTANCE}

Treatment of plant material with compounds, called elicitors, can trigger resistance against stress, and particularly pathogens. Seed treatments with elicitors may be helpful to initiate a defence response early in plant development and has the advantage that it can be applied in a contained environment. Use of resistance inducing compounds is not often pathogen specific, as it has a broad activity spectrum and work against viruses, bacteria and fungi (Hoffland et al., 1996; Park et al., 2008; Pankaj et al., 2013). Low concentrations of the compounds can already elicit a defence response. Many of these compounds work systemically and after seed-treatment may have an effect against root colonizing, soil-borne pathogens and air-borne pathogens affecting haulms. The effect of resistance induction can last during the lifetime of the plant, although often the effect is diminishing in time (Liu et al., 1995). The effect is based on different mechanisms (multitarget) thus reducing risks for resistance development of pathogens. The ecotoxicological risks are considered low, as no biocides are used.

The use of elicitors for seed treatments also knows its limitations, because it often takes 1-7 days before the resistance becomes active. In general, elicitors give a lower level of protection than biocides and rarely provide complete disease control (Walters and Fountaine, 2009). The level of reduction with most inducing agents varies between $20-85 \%$ and therefore the treatments with elicitors can only be one element in an integrated control strategy. The level of protection is dependent on the pathosystem. Induced resistance may be even dependent on the genotype of the plant. Resistance is often more induced in 
relatively susceptible than resistant varieties, as shown for barley treated with $\beta$ aminobutyric acid (Liu et al., 1995; Walters et al., 2011). Similar as for other seed treatments, treatments with elicitors can have a negative impact on plant development.

A wide range of natural compounds can induce resistance in plants against plant pathogens. Some of these have shown to elicit a response after seed treatment. Studies included the use of chemically characterized products, such as proline, chitosan, methyl jasmonate and k-carrageenan, but also crude extracts from bacteria and fungi.

In several studies, the use of chitosan was evaluated for induction of resistance in plants and for its antimicrobial properties. It can also cause swelling and distortion of hyphae in the tomato pathogen Fusarium oxysporum f. sp. lycopersicae (Benhamou, 1992). Seed treatment with chitosan may also influence the microflora in the spermosphere resulting in an increased suppressiveness against soil pathogens. Chitosan will promote the growth of chitinase producing microorganisms, able to degrade the cell wall of plant pathogenic fungi (Bautista-Baños et al., 2006) Treatment of tomato seeds against Fusarium oxysporum f. sp. radicis-lycopersici with chitosan resulted in a systemic acquired resistance (SAR), with a delay of the disease development, but not in a full protection of the seedlings (Benhamou et al., 1994). Treatments resulted in increased levels of phenolic acids and the lignin content. Treatment of soybeans with chitosan resulted in improved germination, more pods, a higher dry weight, a higher average weight of beans with $20 \%$ and a higher percentages of quality beans than the untreated control (Hirano et al., 2001).

Seed treatments with methyl jasmonate, a key signalling molecule in induced resistance responses in plants, is also able to protect seedlings from infections with both aerial and soilborne pathogens. Treatments of melon seed with methyl jasmonate resulted in a control of two soilborne pathogens: Didymella bryoniae, the causative agent of gummy stem blight and Sclerotinia sclerotiorum causing white mould disease (Buzi et al., 2004). The chitinases, peroxidases and lipoxygenase were upregulated in plants raised from treated seeds, indicating a SAR response.

DL- $\beta$-butyric acid (BABA) is an amino acid that is not incorporated in proteins and rarely found in nature (Jakab et al., 2001). However, it has been detected in the root exudates of tomato plants and can therefore be considered as a natural compound. In greenhouse experiments, BABA-treatments of pearl millet resulted in a reduction of the incidence of downy mildew (Sclerospora graminicola) with up to $75 \%$, dependent on the variety used (Shailasree et al., 2001).

Treatments of pearl millet with the amino acid proline, a quencher of reactive oxygen species, resulted in a substantial reduction of downy mildew after artificial inoculation of seedling with its causative agent Sclerospora graminicola (Raj et al., 2004).

In field experiments, treatments of chickpea seed with the elicitor k-carragenan extracted from red algae resulted in plant growth promotion and a considerable increase of induced secondary metabolites, which existed predominantly of phenolic compounds (Bi et al., 2011).

\section{CONCLUSION}

Starting crop production with clean seeds is the background for a healthy crop. Physical seed treatments, natural compounds, microbials and induced resistance are four tools for the control of seedborne diseases with advantages and drawbacks. In organic agriculture, physical seed treatments have the advantage that no expensive and timeconsuming registration of products are needed. Thermotherapy is the most commonly applied seed treatment, in particular to control viruses and bacteria for which only a few alternatives exist.

Biological control, based on the use of antagonistic microorganisms, can be effective and sustainable to control seedborne diseases. From a commercial point of view, complex modes of action make antagonistic performance and efficacy more dependent on production, formulation, packing, application, and storage. A deep understanding of the mode of action is essential to develop appropriate formulation and methods of application, and to obtain registration. Only a few microbial seed treatments for control of seed-borne 
pathogens are commercially available. A similar situation could be described for essential oils and plant extracts, which should be registered for organic seed treatment. Organic acids are used but not registered as crop protection agents. Only a limited number of studies have been conducted on the possibility to treat seeds with elicitors and even less of these studies comprised field experiments. No commercial elicitor products for seed treatments are currently available.

Currently, no single intervention can completely eliminate pathogens from seeds. To ensure the product is healthy and presents the lowest risk possible, a robust multiple-hurdle approach could be implemented. Each step in the handling and processing of seeds provides an opportunity to control pathogens. This approach is based on the use of intervention technologies at critical points throughout the seed production process. Some seed treatments, such as priming, pelletizing, and the use of protectants, can be used by organic farmers to improve seed performance, and to include seedborne control. Integrated control strategies, including different seed treatments, could be helpful to guarantee a high level of disease control and production yield.

\section{ACKNOWLEDGEMENTS}

This review was written in the frame of the European Cooperation in Science and Technology COST Action FA1105 Organic Greenhouse Horticulture - Biogreenhouse and was partly supported by the State Secretariat for Education, Research and Innovation SERI through the Project COST Bioseedling.

\section{Literature cited}

Baker, K. (1962). Thermotherapy of planting material. Phytopathology 52, 1244 10.1094/Phyto-52-1244.

Bautista-Baños, S., Hernández-Lauzardo, A.N., Velázquez-del Valle, M.G., Hernández-López, M., Ait Barka, E., Bosquez-Molina, E., and Wilson, C.L. (2006). Chitosan as a potential natural compound to control pre and postharvest diseases of horticultural commodities. Crop Prot. 25 (2), 108-118 http://dx.doi.org/10.1016/ j.cropro.2005.03.010.

Benhamou, N. (1992). Ultrastructural and cytochemical aspects of chitosan on Fusarium oxysporum f. sp. radicislycopersici, agent of tomato crown and root rot. Phytopathology 82, 1185-1193 10.1094/Phyto-824-1185.

Benhamou, N., Lafontaine, P.J., and Nicole, M. (1994). Induction of systemic resistance to fusarium crown and root rot in tomato plants by seed treatment with chitosan. Phytopathology 84 (12), 1432-1444 http://dx.doi.org/10. 1094/Phyto-84-1432.

Bennett, A.J., and Whipps, J.M. (2008). Beneficial microorganism survival on seed, roots and in rhizosphere soil following application to seed during drum priming. Biol. Control 44 (3), 349-361 http://dx.doi.org/10.1016/ j.biocontrol.2007.11.005.

Bennett, A.J., Mead, A., and Whipps, J.M. (2009). Performance of carrot and onion seed primed with beneficial microorganisms in glasshouse and field trials. Biol. Control 51 (3), 417-426 http://dx.doi.org/10.1016/j. biocontrol.2009.08.001.

Bi, F., Iqbal, S., Arman, M., Ali, A., and Hassan, M. (2011). Carrageenan as an elicitor of induced secondary metabolites and its effects on various growth characters of chickpea and maize plants. J. Saudi Chem. Soc. 15 (3), 269-273 http://dx.doi.org/10.1016/j.jscs.2010.10.003.

Brandl, F., and Biddle, A. (2001). Seed treatment technologies: evolving to achieve crop genetic potential. Paper presented at: International Symposium - Seed Treatment: Challenges \& Opportunities (Wishaw, North Warwickshire, United Kingdom: British Crop Protection Council).

Brown, J., Lu, T., Stevens, C., Khan, V., Lu, J., Wilson, C., Collins, D., Wilson, M., Igwegbe, E., Chalutz, E., and Droby, S. (2001). The effect of low dose ultraviolet light-C seed treatment on induced resistance in cabbage to black rot (Xanthomonas campestris pv. campestris). Crop Prot. 20 (10), 873-883 http://dx.doi.org/10.1016/S02612194(01)00037-0.

Burth, U., Gaber, K., Jahn, M., Lindner, K., Motte, G., Panzer, S., Pflaumbaum, J., and Scholze, F. (1991). Behandlung von Saatgut mittels Elektronen-Ein neues Verfahren zur Bekämpfung samenbürtiger Schaderreger an Winterweizen. Nachrichtenblatt des Deutschen Pflanzenschutzdienstes 43, 41-45.

Buzi, A., Chilosi, G., De Sillo, D., and Magro, P. (2004). Induction of resistance in Melon to Didymella bryoniae and Sclerotinia sclerotiorum by seed treatments with acibenzolar-S-methyl and methyl jasmonate but not with salicylic acid. J. Phytopathol. 152 (1), 34-42 http://dx.doi.org/10.1046/j.1439-0434.2003.00798.x. 
Forsberg, G. (2004). Control of cereal seed-borne diseases by hot humid air seed treatment. Acta Universitatis Agriculturae Sueciae 443.

Gilardi, G., Tinivella, F., Gullino, M., and Garibaldi, A. (2005). Seed dressing to control Fusarium oxysporum f. sp. lactucae. Z. Pflanzenkr. Pflanzenschutz 112, 240-246.

Grondeau, C., Samson, R., and Sands, D.C. (1994). A review of thermotherapy to free plant materials from pathogens, especially seeds from bacteria. Crit. Rev. Plant Sci. 13 (1), 57-75 http://dx.doi.org/10.1080/0735268 9409701908.

Groot, S.P., Van der Wolf, J.M., Jalink, H., Langerak, C.J., and van den Bulk, R.W. (2004). Challenges for the production of high quality organic seeds. Seed Test. Int. 127, 12-15.

Hankin, L., and Sands, D.C. (1977). Microwave treatment of tobacco seed to eliminate bacteria on the seed surface. Phytopathology 77 (6), 794-795 http://dx.doi.org/10.1094/Phyto-67-794.

Hirano, S., Hayashi, M., and Okuno, S. (2001). Soybean seeds surface-coated with depolymerised chitins: chitinase activity as a predictive index for the harvest of beans in field culture. J. Sci. Food Agric. 81 (2), 205-209 http://dx.doi.org/10.1002/1097-0010(20010115)81:2<205::AID-JSFA798>3.0.CO;2-P.

Hoffland, E., Hakulinen, J., and Van Pelt, J.A. (1996). Comparison of systemic resistance induced by avirulent and nonpathogenic Pseudomonas species. Phytopathology 86 (7), 757-762 http://dx.doi.org/10.1094/Phyto-86-757.

Jahn, M., and Puls, A. (1998). Investigations for development of a combined biological-physical method to control soil-borne and seed-borne pathogens in carrot seed. Z. Pflanzenkr. Pflanzenschutz 105, 359-375.

Jakab, G., Cottier, V., Toquin, V., Rigoli, G., Zimmerli, L., Métraux, J.-P., and Mauch-Mani, B. (2001). $\beta$-Aminobutyric acid-induced resistance in plants. Eur. J. Plant Pathol. 107 (1), 29-37 http://dx.doi.org/10.1023/A:1008730721 037.

Jensen, B., Knudsen, I.M.B., Madsen, M., and Jensen, D.F. (2004). Biopriming of infected carrot seed with an antagonist, Clonostachys rosea, selected for control of seedborne Alternaria spp. Phytopathology 94 (6), 551-560. PubMed http://dx.doi.org/10.1094/PHYT0.2004.94.6.551

Jo, Y.-K., Cho, J., Tsai, T.-C., Staack, D., Kang, M.-H., Roh, J.-H., Shin, D.-B., Cromwell, W., and Gross, D. (2014). A Nonthermal plasma seed treatment method for management of a seedborne fungal pathogen on rice seed. Crop Sci. 54 (2), 796-803 http://dx.doi.org/10.2135/cropsci2013.05.0331.

Kasselaki, A.M., Goumas, D., Tamm, L., Fuchs, J., Cooper, J., and Leifert, C. (2011). Effect of alternative strategies for the disinfection of tomato seed infected with bacterial canker (Clavibacter michiganensis subsp. michiganensis). NJAS Wagening. J. Life Sci. 58 (3-4), 145-147 http://dx.doi.org/10.1016/j.njas.2011.07.001.

Knox, O.G., McHugh, M.J., Fountaine, J.M., and Havis, N.D. (2013). Effects of microwaves on fungal pathogens of wheat seed. Crop Prot. 50, 12-16 http://dx.doi.org/10.1016/j.cropro.2013.03.009.

Köhl, J., Postma, J., Nicot, P., Ruocco, M., and Blum, B. (2011). Stepwise screening of microorganisms for commercial use in biological control of plant-pathogenic fungi and bacteria. Biol. Control 57 (1), 1-12 http://dx.doi.org/10.1016/j.biocontrol.2010.12.004.

Ling, K.S. (2010). Effectiveness of chemo- and thermotherapeutic treatments on Pepino mosaic virus in tomato seed. Plant Dis. 94 (3), 325-328 http://dx.doi.org/10.1094/PDIS-94-3-0325.

Links, M.G., Demeke, T., Gräfenhan, T., Hill, J.E., Hemmingsen, S.M., and Dumonceaux, T.J. (2014). Simultaneous profiling of seed-associated bacteria and fungi reveals antagonistic interactions between microorganisms within a shared epiphytic microbiome on Triticum and Brassica seeds. New Phytol. 202 (2), 542-553. PubMed http://dx.doi.org/10.1111/nph.12693

Liu, L., Kloepper, J., and Tuzun, S. (1995). Induction of systemic resistance in cucumber against Fusarium wilt by plant growth-promoting rhizobacteria. Phytopathology 85 (6), 695-698 http://dx.doi.org/10.1094/Phyto-85695.

Lizot, J., Griboval, B., and Guenard, M. (2002). Mise au point d'une technique de disinfection des semences applicable en agriculture biologique - Alternaria dauci sur semences de carottes. Paper presented at: 2ème Conference Internationale sur les Moyens Alternatifs de Lutte contre les Organisms Nuisibles aux Vegetaux (Lille, France).

Matarese, F., Sarrocco, S., Gruber, S., Seidl-Seiboth, V., and Vannacci, G. (2012). Biocontrol of Fusarium head blight: interactions between Trichoderma and mycotoxigenic Fusarium. Microbiology (Reading, Engl.) 158 (1), 98-106. PubMed http://dx.doi.org/10.1099/mic.0.052639-0

McDonald, K.F., Curry, R.D., Clevenger, T.E., Unklesbay, K., Eisenstark, A., Golden, J., and Morgan, R.D. (2000). A comparison of pulsed and continuous ultraviolet light sources for the decontamination of surfaces. IEEE Trans. Plasma Sci. 28 (5), 1581-1587 http://dx.doi.org/10.1109/27.901237. 
Mukerji, K., and Chincholkar, S. (2007). Biological Control of Plant Diseases (Food Products Press).

Pankaj, Muttucumaru, N., Powers, S.J., Gaur, H.S., Kurup, S., and Curtis, R.H.C. (2013). Differential defence response due to jasmonate seed treatment in cowpea and tomato against root-knot and potato cyst nematodes. Nematology 15 (1), 15-21 http://dx.doi.org/10.1163/156854112X641754.

Park, K., Paul, D., Kim, E., and Kloepper, J.W. (2008). Hyaluronic acid of Streptococcus sp. as a potent elicitor for induction of systemic resistance against plant diseases. World J. Microbiol. Biotechnol. 24 (7), 1153-1158 http://dx.doi.org/10.1007/s11274-007-9587-0.

Pill, W., Collins, C., Goldberger, B., and Gregory, N. (2009). Responses of non-primed or primed seeds of 'Marketmore 76'cucumber (Cucumis sativus L.) slurry coated with Trichoderma species to planting in growth media infested with Pythium aphanidermatum. Sci. Hortic. (Amsterdam) 121 (1), 54-62 http://dx.doi.org/10.1016/j.scienta.2009.01.004.

Raj, S.N., Shetty, N.P., and Shetty, H.S. (2004). Proline - an inducer of resistance against pearl millet downy mildew disease caused by Sclerospora graminicola. Phytoparasitica 32 (5), 523-527 http://dx.doi.org/10.1007/BF02980446.

Sagong, H.-G., Lee, S.-Y., Chang, P.-S., Heu, S., Ryu, S., Choi, Y.-J., and Kang, D.-H. (2011). Combined effect of ultrasound and organic acids to reduce Escherichia coli 0157:H7, Salmonella Typhimurium, and Listeria monocytogenes on organic fresh lettuce. Int. J. Food Microbiol. 145 (1), 287-292. PubMed http://dx.doi.org/ 10.1016/j.ijfoodmicro.2011.01.010

Schmitt, A., Koch, E., Stephan, D., Kromphardt, C., Jahn, M., Krauthausen, H., Forsberg, G., Werner, S., Amein, T., Wright, S.A., et al. (2009). Evaluation of non-chemical seed treatment methods for the control of Phoma valerianellae on lamb's lettuce seeds. J. Plant Dis. Prot. 116 (5), 200-207 http://dx.doi.org/10.1007/ BF03356311.

Selcuk, M., Oksuz, L., and Basaran, P. (2008). Decontamination of grains and legumes infected with Aspergillus spp. and Penicillum spp. by cold plasma treatment. Bioresour. Technol. 99 (11), 5104-5109. PubMed http://dx.doi.org/10.1016/j.biortech.2007.09.076

Shailasree, S., Sarosh, B.R., Vasanthi, N.S., and Shetty, H.S. (2001). Seed treatment with $\beta$-aminobutyric acid protects Pennisetum glaucum systemically from Sclerospora graminicola. Pest Manag. Sci. 57 (8), 721-728. PubMed http://dx.doi.org/10.1002/ps.346

Shukla, A.C., Shahi, S.K., Tewari, D.S., and Dikshit, A. (2002). Control of Fusarial wilt diseases of pigeonpea by Trachyspermum ammi. Trop. Agric. 79, 88-93.

Skandamis, P., Koutsoumanis, K., Fasseas, K., and Nychas, G.E. (2001). Inhibition of oregano essential oil and EDTA on Escherichia coli 0157: H7. Ital. J. Food Sci. 13, 65-75.

Spadaro, D., and Gullino, M.L. (2005). Improving the efficacy of biocontrol agents against soilborne pathogens. Crop Prot. 24 (7), 601-613 http://dx.doi.org/10.1016/j.cropro.2004.11.003.

Tinivella, F., Hirata, L.M., Celan, M.A., Wright, S.A.I., Amein, T., Schmitt, A., Koch, E., Van Der Wolf, J.M., Groot, S.P.C., Stephan, D., et al. (2009). Control of seed-borne pathogens on legumes by microbial and other alternative seed treatments. Eur. J. Plant Pathol. 123 (2), 139-151 http://dx.doi.org/10.1007/s10658-008-9349-3.

Van Der Wolf, J.M., Birnbaum, Y., Van Der Zouwen, P.S., and Groot, S.P.C. (2008). Disinfection of vegetable seed by treatment with essential oils, organic acids and plant extracts. Seed Sci. Technol. 36 (1), 76-88 http://dx.doi.org/ 10.15258/sst.2008.36.1.08.

Walters, D.R., and Fountaine, J.M. (2009). Practical application of induced resistance to plant diseases: an appraisal of effectiveness under field conditions. J. Agric. Sci. 147 (05), 523-535 http://dx.doi.org/10.1017/S002 1859609008806.

Walters, D.R., Havis, N.D., Paterson, L., Taylor, J., and Walsh, D.J. (2011). Cultivar effects on the expression of induced resistance in spring barley. Plant Dis. 95 (5), 595-600 http://dx.doi.org/10.1094/PDIS-08-10-0577.

Wharton, P.S., Kirk, W.W., Schafer, R.L., and Tumbalam, P. (2012). Evaluation of biological seed treatments in combination with management practices for the control of seed-borne late blight in potato. Biol. Control 63 (3), 326-332 http://dx.doi.org/10.1016/j.biocontrol.2012.09.005.

Zhang, S., White, T.L., Martinez, M.C., McInroy, J.A., Kloepper, J.W., and Klassen, W. (2010). Evaluation of plant growth-promoting rhizobacteria for control of Phytophthora blight on squash under greenhouse conditions. Biol. Control 53 (1), 129-135 http://dx.doi.org/10.1016/j.biocontrol.2009.10.015. 
